\title{
Media Relations di Era Konglomerasi Media
}

\author{
Sumantri Raharjo \\ Dosen Tetap Akademi Komunikasi Indonesia (AKINDO), Yogyakarta
}

\begin{abstract}
Every organization needs mass media to publish positive news for their image. It will be a serious problem when media is in a ring with the others commercial corporate ownership. Public Relations practitioners have to map all media around them to prevent a blunder strategics to reach organization objective on media relations. It is very risky when organization misselects the groups of media to reach their goal. A good analysis of media groups mapping can avoid a blunder strategy.
\end{abstract}

Keywords: public relations, media relations, media conglomeration, media ownership.

\begin{abstract}
Abstrak
Setiap organisasi memerlukan media massa untuk mempublikasikan berita positif untuk membentuk citra organisasi tersebut. Maka, akan menjadi permasalahan serius ketika media berada dalam arena yang sama dengan korporasi komersil - dalam hal kepemilikan. Praktisi Humas harus melakukan pemetaan terhadap media di sekitarnya untuk menghindari strategi yang keliru dalam mencapai tujuan organisasi terkait dengan relasi media. Sangatlah berisiko ketika sebuah organisasi salah memilih grup media dalam rangka mencapai tujuan. Maka, analisis yang baik dalam pemetaan grup media akan membantu organisasi menghindari "blunder" ini.
\end{abstract}

Kata Kunci: hubungan masyarakat, hubungan media, konglomerasi media, kepemilikan media.

\section{Pendahuluan}

Kegiatan menjalin hubungan dengan media merupakan hal yang sangat penting bagi perusahaan atau organisasi untuk menciptakan citra korporasi maupun produk. Hubungan media yang baik akan sangat membantu perusahaan meningkatkan kesadaran terhadap eksistensi korporasi dan/atau produknya. Selama ini perusahaan melakukan banyak strategi untuk menjalin relasi dengan media baik cetak maupun elektronik demi mencapai efektivitas publisitas.

Strategi menjalin hubungan dengan media dilakukan mulai dari pemilihan media yang tepat, level hubungan yang dibangun, hingga memiliki media sendiri. Pemilihan media akan sangat menentukan ketepatan sasaran publikasi. Pemilihan media dilakukan melalui media mapping pada semua media yang ada dan dianggap potensial berdasarkan profil yang 
dimilikinya, yang ditindaklanjuti dengan menentukan media-media yang akan dijadikan partner publikasi.

Secara umum, perspektif dan faktor pemilihan media (H.S.Bok dkk, 2012) antara lain meliputi:

Karakteristik media; (2) Faktor sosial; (3) Fitur individu; dan (4) Faktor kontekstual. Sementara, karakter media mencakup: faktor sosial media, tingkat kesempurnaan isi, tingkat kewajaran, simbol media, dan tingkat kesingkronan media. Faktor sosial mencakup tingkat pengaruh media dan tingkat reaksi atau kekritisan audiens media. Fitur individu mencakup karakter audiens dan tingkat pengalamannya terhadap media dan pesan. Sedangkan faktor kontekstual mencakup aksesibilitas terhadap media, ketersediaan ruang di media, dan faktor-faktor yang bersifat organisasional.

Faktor-faktor di atas secara keseluruhan sangat penting dalam proses seleksi, ketika setiap media dapat dianalisis berdasarkan indikator kebutuhan setiap organisasi. Artinya, semakin banyak media memenuhi kriteria, maka semakin layak media tersebut untuk dipilih. Faktor karakter individu yang menjadi sasaran publikasi merupakan awal penentu pemilihan media. Semakin banyak kesamaan karakter audiens media dengan publik perusahaan, maka efektivitas publikasi juga semakin tinggi. Pemilihan media yang sesuai dengan publik menurut Bland (2005) merupakan langkah awal dalam kegiatan media relations. Proses verifikasi antara target khalayak organisasi (perusahaan) dan audiens dari media akan sangat menentukan seberapa layak sebuah media dijadikan sarana membangun kesadaran terhadap eksistensi produk dan korporasi.

Bagaimanapun, pertimbangan kesesuaian khalayak organisasi dan audiens media bukanlah satu-satunya faktor yang menentukan keberhasilan publikasi dalam konteks media relations. Jenis media, jangkauan media, dan level hubungan organisasi-media juga akan menentukan keberhasilan publikasi. Jenis media dikategorikan dalam media cetak (surat kabar, tabloid, dan majalah), media elektronik (radio dan televisi), dan media online (internet). Jangkauan media selain berkaitan dengan jenis media, juga dengan jumlah audiens. Jangkauan media cetak ditentukan oleh jumlah eksemplar dan cakupan wilayah sebaran (lokal, regional, nasional, atau internasional). Media radio dan televisi tentu selain memperhatikan jangkauan wilayah siaran sebagai media lokal atau nasional, rating acara juga menjadi faktor penting dalam melakukan pilihan media. Sedangkan jangkauan media online secara geografis tidak ada batasan, namun kuantitas pengunjung situs akan menentukan tingkat popularitas maupun tingkat akses terhadap media tersebut. Namun demikian, saat ini sudah banyak media konvensional yang juga merambah media online dengan streaming maupun portal 
berita, sehingga wilayah geografis tidak lagi menjadi kendala yang berarti.

Pilihan media yang tepat tidak akan menjamin efektivitas publikasi tanpa strategi dan teknik media relations yang baik. Salah satu teknik yang menentukan kegiatan keberhasilan dalam media relations adalah dengan meningkatkan level hubungan yang tidak hanya bersifat teknis tapi juga emosional. Selain itu, perbedaan hubungan dengan struktur jabatan antara organisasi dan media akan memengaruhi efektivitas publikasi. Semakin tinggi struktur jabatan seseorang di media yang diajak berelasi, maka akan semakin besar peluang untuk melakukan publikasi. Sebagai ilustrasi, hubungan yang dilakukan melalui redaktur akan lebih kuat dibandingkan hanya dengan wartawan. Selain itu seorang redaktur berhak menentukan sebuah berita diliput ataupun dimuat oleh media.

Kedekatan emosional akan sangat membantu untuk menutup kekurangan dalam teknik penulisan rilis, karena redaktur atau wartawan yang sudah dekat secara psikologis tidak akan sungkan membantu perusahaan mengoreksi kesalahan maupun mengedit materi berita. Selain itu, kedekatan secara emosi juga akan memangkas birokrasi hubungan seperti surat-menyurat secara resmi untuk mengundang media dalam liputan event dan digantikan dengan pesan singkat (SMS), Blackberry Message (BBM), email, ataupun telepon secara informal.
Dalam kondisi objektif, ketika media merupakan stakeholder eksternal, maka masing-masing organisasi mempunyai kesempatan yang sama dalam mempublikasikan agenda ataupun peristiwa yang berkaitan dengan perusahaan mereka. Mereka akan berebut ruang dengan menampilkan kualitas kegiatan dan nilai kemanfaatannya bagi masyarakat untuk menjadi sebuah berita. Selektivitas redaktur media yang akan menentukan berita layak dimuat atau tidak, atau langsung dimuat atau ditunda.

Persoalannya, saat ini banyak media yang berada dalam satu jaringan usaha. Hal ini tidak hanya dalam satu jenis media tapi juga berbagai jenis dari cetak, radio, televisi,dan bahkan media portal (internet online). Selain itu, beberapa jaringan media juga berjaringan dengan usaha-usaha komersil nonmedia. Fenomena ini tentu sangat memengaruhi peta persaingan dalam pemanfaatan media sebagai ruang publikasi. Dari perspektif usaha, hal ini merupakan sesuatu yang sengaja diciptakan untuk memangkas tingkat persaingan organisasi di redaksi dan sekaligus menghidupkan perusahaan media di sisi yang lain.

Jaringan usaha media dan nonmedia akan membuat efektivitas kegiatan media relations sangat debatable ketika perusahaan lebih banyak menggunakan media yang masih dalam satu kelompok usaha. Hal ini terkait dengan tingkat kepercayaan masyarakat terhadap perusahaan dan tingkat 
kepercayaan masyarakat terhadap media yang digunakan. Publisitas melalui media dalam satu kelompok usaha jelas akan lebih mudah dalam hal akses, namun akan sangat kontroversial dalam hal objektifitas dan kepercayaan. Nilai publikasi organisasi yang dimuat dalam media satu jaringan hampir tidak ada bedanya dengan iklan atau promosi yang sangat dikendalikan oleh klien, serta lemah dalam pengawasan akibat dari kepentingan yang lebih besar.

Namun demikian, ini masih sangat tergantung pada kekuatan media dalam memengaruhi audiensnya. Jika media sangat kuat, maka pengaruhnya juga besar sehingga model konglomerasi media dengan usaha akan membuahkan hasil. Konteks keberhasilan itu terjadi apabila masyarakat juga kurang cerdas dalam melakukan pemilihan media untuk kebutuhan informasinya, termasuk dalam mencari media pembanding. Audiens yang cerdas akan membandingkan isi informasi satu media dengan media yang lain dengan tingkat kekritisannya masingmasing. Pembaca, pendengar, dan pemirsa yang kritis akan bisa membedakan informasi secara lebih objektif dan tidak mudah percaya terhadap bingkai pemberitaan yang dibangun oleh sebuah media tanpa membandingkannya dengan perspektif media yang lain.

Persoalan yang sering terjadi, banyak orang hanya mengkonsumsi berita dari satu sumber dan menganggap hal tersebut sebagai suatu kebenaran. Kebenaran versi media tersebut kemudian dianggap sebagai kebenaran yang harus diikuti sehingga ini akan bias jika kemudian menyangkut persoalan hukum yang masih harus dibuktikan kebenarannya berdasarkan hukum positif. Perspektif hubungan masyarakat akan melihat kelayakan media dijadikan partner dan efektivitasnya dalam menjangkau dan memengaruhi pandangan masyarakat (publik) terhadap organisasinya.

\section{Pembahasan}

\section{Konglomerasi Media di Indonesia}

Konglomerasi media di Indonesia mulai tumbuh pesat sejak kejatuhan pemerintahan Orde Baru yang dipimpin mantan Presiden Suharto pada tahun 1997. Sejak saat itu, perkembangan media bagaikan jamur di musim hujan. Banyak kelompok kepemilikan media seperti terdata sebagai berikut: 
Sumantri Raharjo, Media Relations di Era Konglomerasi Media

Tabel Kelompok Konglomerasi Media di Indonesia

\begin{tabular}{|c|c|c|c|c|c|c|c|}
\hline No & $\begin{array}{c}\text { Kelompok } \\
\text { Media }\end{array}$ & Surat Kabar & Majalah & Radio & Televisi & Media Online & Bisnis lain \\
\hline 1 & $\begin{array}{l}\text { Kompas- } \\
\text { Gramedia } \\
\text { Group }\end{array}$ & $\begin{array}{l}\text { Kompas, Jakarta } \\
\text { Post, Warta Kota, } \\
\text { dan 11 surat kabar } \\
\text { lokal }\end{array}$ & $\begin{array}{l}37 \text { majalah } \\
\text { dan tabloid, } 5 \\
\text { penerbit buku }\end{array}$ & $\begin{array}{l}\text { Sonora } \\
\text { dan } \\
\text { Otomo- } \\
\text { tion }\end{array}$ & $\begin{array}{l}\text { Kompas } \\
\text { TV }\end{array}$ & $\begin{array}{l}\text { Kompas.com, } \\
\text { kompasiana.com }\end{array}$ & $\begin{array}{l}\text { Hotel Santika Group, } \\
\text { Printing House, } \\
\text { Promotion Agencies, } \\
\text { Universitas }\end{array}$ \\
\hline 2. & $\begin{array}{l}\text { MNC (Media } \\
\text { Nusantara } \\
\text { Citra) }\end{array}$ & Seputar Indonesia & $\begin{array}{l}\text { Genie, Mom \& } \\
\text { Kiddy, Realita, } \\
\text { Majalah Trust }\end{array}$ & $\begin{array}{l}\text { Trijaya } \\
\text { FM, } \\
\text { Radio } \\
\text { Dangdut } \\
\text { TPI, ARH } \\
\text { Global, } \\
\text { Women } \\
\text { Radio }\end{array}$ & $\begin{array}{l}\text { RCTI, } \\
\text { Global TV, } \\
\text { MNC TV, } \\
\text { Indovision }\end{array}$ & Okezone.com & IT Businnes \\
\hline 3 & Jawa Pos & $\begin{array}{l}\text { Jawa Pos, Fajar, } \\
\text { Riau Pos, Rakyat } \\
\text { Merdeka, dan 90 } \\
\text { Surat Kabar Lokal }\end{array}$ & $\begin{array}{l}23 \text { Majalah } \\
\text { Mingguan }\end{array}$ & Fajar FM & $\begin{array}{l}\text { JTV dan } 3 \\
\text { TV lokal }\end{array}$ & & $\begin{array}{l}\text { Biro Travel, Power } \\
\text { House }\end{array}$ \\
\hline 4 & $\begin{array}{l}\text { Mugi Reka } \\
\text { Aditama } \\
\text { (MBA) }\end{array}$ & & $\begin{array}{l}\text { Cosmopolitan, } \\
\text { Harper's } \\
\text { Bazaar, } \\
\text { Esquire, FHM, } \\
\text { Good House } \\
\text { Keeping, dan } \\
\text { 10 majalah } \\
\text { lain }\end{array}$ & $\begin{array}{l}\text { Hard } \\
\text { Rock FM, } \\
\text { MTV Sky }\end{array}$ & O Channel & & $\begin{array}{l}\text { Pemilik sejumlah } \\
\text { International } \\
\text { Boutique }\end{array}$ \\
\hline 5 & Bali Post & $\begin{array}{l}\text { Bali Post, Suluh } \\
\text { Indonesia, dan } 2 \\
\text { koran lain }\end{array}$ & Tabloid Tokoh & & $\begin{array}{l}\text { Bali Tv dan } \\
8 \text { TV lokal } \\
\text { lain }\end{array}$ & $\begin{array}{l}\text { Bali Post, Bisnis } \\
\text { Bali }\end{array}$ & \\
\hline 6 & $\begin{array}{l}\text { Mahaka } \\
\text { Media }\end{array}$ & Harian Republika & $\begin{array}{l}\text { Golf Digest, } \\
\text { Arena, Parents } \\
\text { Indonesia, A+ }\end{array}$ & Jak FM & $\begin{array}{l}\text { Jak TV, TV } \\
\text { One } \\
\text { (bersama } \\
\text { Bakrie } \\
\text { Group) }\end{array}$ & & $\begin{array}{l}\text { Entertainment, } \\
\text { Outdoor Advertise- } \\
\text { ment }\end{array}$ \\
\hline 7 & $\begin{array}{l}\text { Femina } \\
\text { Group }\end{array}$ & & $\begin{array}{l}\text { Femina, Gadis, } \\
\text { Ayahbunda, } \\
\text { Dewi, dan } 10 \\
\text { majalah lain }\end{array}$ & $\begin{array}{l}\text { Radio U } \\
\text { FM }\end{array}$ & & & Production House \\
\hline 8 & $\begin{array}{l}\text { Bakrie } \\
\text { Group }\end{array}$ & & & & $\begin{array}{l}\text { ANTV, TV } \\
\text { One }\end{array}$ & Viva-news.com & $\begin{array}{l}\text { Property, Mining, } \\
\text { Palm Oil, dan } \\
\text { Telekomunikasi }\end{array}$ \\
\hline 9 & Lippo Group & $\begin{array}{l}\text { Jakarta Globe, } \\
\text { Investor daily, } \\
\text { Suara Pembaruan }\end{array}$ & $\begin{array}{l}\text { Majalah } \\
\text { Investor, } \\
\text { Globe Asia, } \\
\text { Campus Asia }\end{array}$ & & & Beritasatu.com & $\begin{array}{l}\text { Property, Hospital, } \\
\text { Education, } \\
\text { Insurance, ISP }\end{array}$ \\
\hline 10 & Trans Corp & & & & $\begin{array}{l}\text { Trans TV, } \\
\text { Trans } 7\end{array}$ & Detik.com & $\begin{array}{l}\text { Bank Mega, Trans } \\
\text { Studio, Para } \\
\text { Multifinance, dan } \\
\text { beberapa usaha } \\
\text { hiburan serta gaya } \\
\text { hidup }\end{array}$ \\
\hline 11 & $\begin{array}{l}\text { Media } \\
\text { Group }\end{array}$ & $\begin{array}{l}\text { Media Indonesia, } \\
\text { Lampung Post, } \\
\text { Borneo News }\end{array}$ & & & Metro TV & $\begin{array}{l}\text { Media } \\
\text { Indonesia.com }\end{array}$ & \\
\hline
\end{tabular}

Sumber: dikembangkan dari Firdaus Cahyadi, www.satudunia.com 
Data konglomerasi media di atas menunjukkan dua hal penting. Pertama, adanya kelompok kepemilikan media yang usahanya hanya fokus pada industri media saja seperti Media Group dan Bali Post Group. Kedua, industri media yang tidak berdiri sendiri, tapi juga merupakan bagian dari kepentingan bisnis yang lebih besar yang membutuhkan kehadiran media sebagai alat untuk membangun bisnis mereka dan sebagai bisnis itu sendiri.

Jenis kelompok yang pertama, yaitu media menjadi dari bagian dari kelompok media saja, maka independensinya secara umum akan lebih baik dibandingkan dengan kelompok kedua. Objektivitas media dalam memberitakan kepentingan dunia usaha juga relatif mempunyai jarak untuk menampilkan data dan fakta secara proporsional dan transparan. Keberagaman media, dalam jenis ini semakin beragamnya isi, audiens, dan kebijakan redaksi, akan semakin mendukung iklim demokrasi dalam masyarakat dan negara. Secara umum kelompok ini cenderung mempunyai pengaruh positif terhadap masyarakat. Kelompok ini juga memiliki potensi besar untuk dijadikan sebagai media partner dalam memperluas jangkauan publikasi secara masif untuk kepentingan organisasi, dengan mempertimbangkan efisiensi energi dalam pemetaan dan pendekatan terhadap media.

Sementara itu, organisasi di luar jaringan usaha harus ekstra hati-hati untuk memanfaatkan media kelompok kedua untuk kepentingan publikasi. Ada tiga pertimbangan utama untuk melihat kelayakan kerja sama dengan kelompok ini. Pertama, Kesamaan jenis usaha organisasi dengan kelompok usaha yang dimiliki jaringan usaha tersebut. Motif persaingan menjadi alasan utama ketika media akan mengutamakan kepentingan organisasi dalam satu kelompok usaha daripada usaha di luar lingkaran kelompok. Organisasi luar harus melakukan analisis dengan sangat cermat jika ingin bekerja sama dalam konteks publikasi.

Kedua, tingkat integrasi antara usaha media dan usaha nonmedia yang berada dalam satu lingkaran kepemilikan. Sebagian besar pengusaha memiliki usaha media dan nonmedia sebagai bagian dari strategi pencapaian bisnis secara terintegrasi. Itu berarti antara bisnis satu dengan yang lain tidak berdiri sendirisendiri, melainkan saling mengisi dan membantu pengembangan antarunit usaha. Setiap jenis usaha dalam kelompok semacam ini sudah diberikan peran dalam mendukung tercapainya tujuan besar kelompok usaha. Kondisi semacam ini akan sulit dimanfaatkan oleh organisasi di luar lingkaran usaha, kecuali organisasi 
tersebut mempunyai kelebihan yang tidak dimiliki oleh kelompok usaha sehingga berpotensi untuk menutup kekurangan yang dimiliki oleh kelompok usaha tersebut.

Dalam kondisi tersebut, secara umum media cenderung berpotensi untuk berdampak negatif, khususnya bagi perkembangan organisasi di luar jaringan usaha secara khusus dan demokrasi dalam masyarakat dan negara secara umum. Semakin besar jaringan usaha, akan semakin berbahaya, sebab mereka akan mematikan potensi-potensi di luar jaringan dan cenderung menguasai industri hulu hingga hilir. Media dalam kelompok usaha secara umum digunakan untuk mendukung tujuan kelompok yang cenderung akan meminimalisir diversitas opini dalam masyarakat. Jika jumlahnya banyak dan menyebar secara geografis, jaringan tersebut akan mendominasi wacana dan mempersempit realitas pandangan masyarakat terhadap sebuah objek.

Ketiga, kredibilitas kelompok usaha. Kelompok usaha yang kredibel terutama medianya akan mudah mendapatkan kepercayaan dari masyarakat luas, maka jika organisasi di luar kelompok bisa memanfaatkan hubungan yang baik, kredibitasnya juga akan terangkat. Sebaliknya, jika kelompok usaha atau medianya tidak punya kredibilitas yang cukup, lebih baik dihindari agar tidak berdampak negatif terhadap citra yang sudah dimilikinya.
Kredibilitas kelompok secara keseluruhan harus dilihat, baik bisnis media maupun nonmedia. Pencitraan masing-masing organisasi sebagai bagian dari kelompok akan membawa konsekuensi pada penilaian akhir. Pertimbangan dalam menetapkannya harus menggunakan model analisis multiple image dan sangat tergantung pada konteks tujuan kerja sama.

Dalam perkembangannya, konglomerasi media tidak hanya bersifat harisontal (mono-media-concentrations hanya satu jenis saja, misalnya media cetak) tapi sudah bersifat diagonal (cross media concentration - lebih dari satu jenis media, misalnya: cetak, elektronik [radio, tv] dan media online). Ini menandai era konvergensi media yang lebih dulu ditangkap oleh para pengusaha untuk mencapai banyak kepentingan. Jenis konglomerasi media diagonal secara objektif akan menguntungkan organisasi di luar lingkaran kelompok untuk kepentingan media relations. Organisasi tidak perlu mengejar jumlah media yang menjadi partner kerja sama, tapi cukup dengan menjalin hubungan dengan satu atau dua kelompok usaha media berjenis diagonal untuk menjangkau publik yang berbeda baik secara geografis, demografis, maupun psikografis. Sebaran publikasi dengan variasi media yang lebih beragam akan memperluas jangkauan publik dengan usaha yang minimal.

Ekspansi dan konglomerasi media yang dilakukan oleh media, secara umum 
memiliki dua tendensi kepentingan berkaitan dengan kebijakan (Doyle, 2002). Pertama, potensi implikasi sosial politik dan budaya yang diinginkan dari perusahaan media. Kedua, berkaitan dengan potensi ekonomi yang ingin diraih dari pengembangan usaha media. Implikasi sosial politik dan budaya berkaitan dengan pluralisme media, ketika keanekaragaman media dengan perbedaan suara yang independen mengacu pada opini politik yang merepresentasikan budaya-budaya dalam media. Lepas dari tendensi ekonomi, masyarakat luas tentu berharap adanya keberagaman dan pluralisme baik dalam isi maupun sumber media. Secara ideal, masyarakat juga berharap adanya keberagaman dalam kepemilikan yang kemungkinan besar akan berimplikasi pada perbedaan kebijakan dalam mengelola organisasi media.

Sedangkan orientasi ekonomi lebih mengacu pada dominasi pasar dan dominasi keuntungan. Konglomerasi media dalam hal ini cenderung untuk membentuk kelompok usaha dengan konsentrasi sumber daya manusia secara efisien dalam media yang beragam. Media dalam satu jaringan kelompok usaha menunjuk pada kepentingan akses media yang lebih mudah dan lebih efisien, ketika para pengusaha akan melakukan publikasi bisnis dengan media yang dimiliki sendiri dibanding dengan penggunaan media di luar jaringan bisnis. Efisiensi juga mencakup penggunaan sumber daya manusia terutama untuk konglomerasi secara diagonal ketika antarmedia bisa saling memanfaatkan SDM dalam mencari ataupun bertukar materi informasi.

Secara bisnis, strategi ini sangat menguntungkan pengusaha. Namun, dalam perspektif demokrasi maupun pencerdasan kehidupan, ini akan membelenggu masyarakat (audiens) pada keterbatasan pilihan informasi yang dimonopoli atau oligopoli oleh para pengusaha. Selain itu pandangan sosial politik dan budaya dari seorang pengusaha sedikit banyak akan memengaruhi kebijakan perusahaan secara keseluruhan dan redaksi secara khusus. Dalam hal ini, konsentrasi ekonomi maupun sosial politik dan budaya dari konglomerasi cenderung berkorelasi negatif dengan konsentrasi keberagaman dan pluralisme yang diharapkan oleh masyarakat.

Penelitian tentang konglomerasi media dan berita di Amerika yang dilakukan oleh Smith dan Carachiolo (2007) menunjukkan bahwa masyarakat cenderung tidak percaya terhadap pemberitaan perusahaan raksasa yang menguasai banyak media. Perusahaan raksasa itu cenderung mengejar kepentingan ekonomi sehingga publik diliputi keragu-raguan dan sikap skeptis terhadap pers.

Beberapa penelitian terhadap sejumlah program di media televisi di Indonesia juga menunjukkan bahwa 
media telah melakukan komodifikasi nilai-nilai berita, budaya, dan religi untuk meraih keuntungan secara ekonomi. Hal ini menunjukkan bahwa kepentingan masyarakat terhadap media secara ideal cenderung terpinggirkan oleh kepentingan komersial. Kebutuhan masyarakat terhadap pemberitaan dan informasi juga terganggu oleh motif media yang lebih mengutamakan kepentingan ekonomi daripada sebagai sumber informasi, sehingga berita bisa berubah menjadi komoditas yang bisa diatur dan dibeli oleh kelompok tertentu. Ini seharusnya menjadi bahan pertimbangan penting bagi para praktisi hubungan masyarakat (public relations) dalam melakukan pemetaan media sebagai sarana publikasi berdasarkan fenomena kepemilikan media yang terjadi pada saat ini. Sedapat mungkin, organisasi menghindari mediamedia yang berada dalam satu jaringan dengan usaha-usaha nonmedia, terutama yang memiliki kesamaan jenis usaha. Tujuannya adalah agar tidak terjadi konflik kepentingan.

Pemetaan media tidak hanya dilakukan terhadap media-media baru tetapi juga dilakukan secara rutin terhadap media-media lama yang telah melakukan kerja sama. Pada hakikatnya, seperti usaha-usaha lain, media juga memiliki kemungkinan mengalami perubahan baik kepemilikan, kebijakan organisasi usaha, maupun kebijakan redaksional. Fenomena akuisisi media baik oleh pengusaha media maupun nonmedia seringkali terjadi. Hal seperti ini akan menunjukkan relevansi dengan kebijakan media sebagai organisasi usaha maupun kebijakan redaksional. Masingmasing perubahan kebijakan akan membawa konsekuensi pada pemetaan yang dilakukan berkaitan dengan tingkat kelayakan penggunaan media sebagai partner.

Pemetaan secara rutin akan membuat organisasi lebih waspada terhadap potensi-potensi negatif. Hal ini dalam jangka panjang juga memberikan stabilitas keberhasilan kegiatan media relations yang dilakukan secara berkelanjutan.

\section{Media Relations dengan Media dalam Satu Kelompok Usaha}

Secara umum, organisasi akan sangat diuntungkan ketika mereka mempunyai relasi yang baik dengan kelompok media berjaringan. Hal ini akan menciptakan efisiensi kerja dan efektivitas publikasi yang tinggi dalam menjangkau khalayak. Jaringan media akan sangat membantu memperluas jangkauan dan variasi segmentasi khalayak. Sebuah pesan akan menjangkau khalayak yang berbeda-beda secara demografis, psikografis, bahkan geografis. Selain kepentingan organisasi yang lebih mudah dipublikasikan, prioritas yang jauh lebih penting adalah media-media yang ada juga bisa digunakan sebagai sarana untuk memperbaiki citra yang sedang buruk 
maupun menangkal berita atau isu negatif yang berkembang di masyarakat.

Penyebaran publikasi yang serentak dan bersifat homogen melalui jaringan media yang heterogen akan memberikan pengaruh positif untuk mengklarifikasi hal-hal yang berpotensi merugikan organisasi. Hal ini akan lebih efektif jika media-media tersebut memiliki karakter kuat dan dipercaya oleh masyarakat sebagai sumber informasi yang kredibel.

Berlawanan dengan kepentingan di atas, perspektif pemanfaatan media berjaringan harus dipertimbangkan secara hati-hati untuk dijadikan sarana publikasi bagi organisasi. Homogenitas pemberitaan justru akan sangat mengganggu kesadaran khalayak terutama berkaitan dengan isu-isu sensitif dan ada kemungkinan menimbulkan persepsi yang cenderung memperlemah citra media maupun organisasi di mata audiens (publik). Kolaborasi industri dan media dalam satu jaringan bisnis akan mengganggu objektivitas penilaian masyarakat terhadap isu-isu yang berkembang, kecuali keduanya samasama mempunyai kredibilitas yang baik di mata masyarakat. Materi berita yang didominasi oleh kepentingan dan perspektif kelompok bisnis akan mempersempit pilihan masyarakat dalam memberikan persepsi dan menyikapi persoalan-persoalan yang ada sehingga realitas media akan mendominasi wacana publik. Kondisi seperti ini cenderung akan memperkukuh realitas media dalam mendominasi realitas masyarakat. Dalam perspektif media relations yang cenderung negatif, berita akan menjadi alat promosi kepentingan sebagaimana halnya iklan. Jika ini terjadi, maka kepercayaan masyarakat justru akan menurun dan citra yang diharapkan tidak akan tercapai.

Independensi media yang menjadi bagian dari kelompok industri nonmedia akan sangat bias ketika mereka memberitakan industri kelompoknya tersebut. Kontrol terhadap materi berita dari perusahaan yang masih dalam satu kelompok usaha tentu tidak akan seketat jika memberitakan industri di luar kelompok usaha, dan bahkan akan cenderung oposisi jika memberitakan industri pesaing. Ini tentu akan membuat media justru menjadi pemicu persoalan dan menciptakan persaingan yang tidak sehat.

Secara lebih luas, jika media di suatu negara hanya dimiliki oleh beberapa gelintir orang atau kelompok-kelompok tertentu saja, maka sebenarnya negara tersebut sedang mengalami masalah serius dalam kebebasan pers dan demokrasi. Konglomerasi media dalam konteks ini cenderung akan melemahkan demokrasi dan keberagaman ide dalam masyarakat. Mereka menguasai agendaagenda besar yang harus diangkat dalam masyarakat dan mengarahkan agenda masyarakat untuk mendukung ide-ide mereka atau kelompok mereka. 
Kemampuan sensor media akan sangat lemah dan mengutamakan kepentingan kelompok serta bisnis yang melatarbelakanginya.

Hal ini tidak hanya terjadi di Indonesia. Negara-negara yang menganut paham liberal juga memiliki kondisi yang sama, dengan kemungkinan lebih ekstrem. Menurut Laporan Mother Jones Magazine, sampai akhir 2006 media di Amerika didominasi oleh 8 kelompok raksasa yaitu Disney, AOL-Time Warner, Viacom, General Electic, News Coporation, Yahoo!, Microsoft, dan Google (www.globalissues.org).

Masalah kepemilikan media memang menjadi titik krusial jika tidak diatur dengan cermat. Persaingan usaha dan pembentukan opini publik menjadi kepentingan yang tidak terelakkan, sehingga akan lebih sehat kondisinya jika pemilik media bukanlah pengusaha nonmedia. Namun demikian, di Indonesia hal ini sudah terjadi dan tidak terhindarkan. Persaingan antar industri juga telah berkembang menjadi persaingan opini antarmedia, terutama untuk para pengusaha yang perusahaannya sedang atau dianggap bermasalah. Sebagai contoh, media kelompok usaha Bakrie menggunakan istilah "Lumpur Sidoarjo" dalam pemberitaan tentang kasus semburan lumpur di Sidoarjo yang populer di masyarakat dengan "Lumpur Lapindo". Hal ini tentu tidak terlepas dari pengaruh kepemilikan media oleh pengusaha.
Akhirnya pemilik dan media yang berada dalam satu kelompok usaha cenderung menentang arus pemberitaan media lain.

Hal semacam ini juga menjadi catatan serius Vice Presiden Corporate Communication PT. Pertamina, Mochamad Harun ${ }^{1}$ dalam seminar "Strategi PR di Perusahaan Tambang". Menurutnya, kepemilikan media oleh para pengusaha (nonmedia) akan memunculkan masalah tersendiri ketika terjadi konflik antarindustri. Konflik antarpengusaha sangat mungkin terjadi, dan ketika para pengusaha tersebut juga memiliki media maka akan terjadi perang opini dan tentu saja meluas menjadi perang media. Media yang satu akan menjatuhkan media lain. Keadaan ini akan membuat masyarakat menjadi bingung dan cenderung skeptis.

Kondisi ini akan diperparah oleh fenomena bahwa media tidak hanya satu kelompok dengan perusahaan nonmedia, tapi mereka juga berafiliasi secara politik karena pemiliknya aktif sebagai politikus di negeri ini. Ketika perspektif politik dan persoalan hukum bercampur, nilai kebenaran akan semakin kabur karena kebenaran politik dan kebenaran hukum merupakan dua hal yang sangat berbeda dan susah dipersatukan dalam satu titik temu.

\footnotetext{
${ }^{1}$ Mochammad Harun, materi diskusi dalam seminar "Strategic Role of PR in Crisis Management" pada Seminar Nasional di UPN Veteran Yogyakarta, 21 Juni 2012.
} 


\section{Media Relations dengan Kelompok Media Berafiliasi Politik}

Kait-mengait antara perusahaan, media, dan dunia politik, bukan hal yang asing di Indonesia. Jalannya dunia usaha dan perusahaan dipengaruhi salah satunya oleh kondisi politik dan segala kebijakan yang berhubungan. Hidup perusahaan tidak pernah lepas dari kondisi politik yang sedang berlangsung. Usaha akan lebih kondusif jika situasi politik juga mendukung. Hal inilah yang kemudian memunculkan ide-ide pemanfaatan hubungan antara usaha media, usaha nonmedia, dan politik.

Relasi ketiga faktor tersebut sangat kuat untuk mendukung kesuksesan seseorang ataupun kelompok. Kronologi kesuksesan bisa dimulai dari faktor mana saja dari ketiga faktor tersebut. Banyak pengusaha yang memasuki dunia politik untuk memperlancar bisnis yang dibangunnya, di sisi lain para politisi juga memanfaatkan posisinya untuk membangun bisnis. Keterkaitan dua kepentingan tersebut dengan pemanfaatan media. Ini membuka peluang para pemilik media untuk mendapatkan posisi politik di partai dengan media yang dimilikinya. Keterkaitan antara ketiganya membuat seseorang kemudian berusaha untuk mendapatkan ketiganya sebagai sarana dalam meraih kesuksesan: menjadi pengusaha, pemilik media, sekaligus politikus.
Masalah menjadi semakin kompleks ketika dunia usaha dan politik memengaruhi kebijakan redaksional. Bagaimanapun eksistensi media akan memengaruhi pandangan politik dan kebijakan pemerintah, media yang dikuasai oleh pengusaha yang terjun di dunia politik akan membuat demokrasi semakin terpinggirkan. Orientasi media menjadi tidak netral dan jauh dari nilainilai ideal. Mereka akan memanfaatkan media untuk kepentingan politik dan sekaligus kebijakan pemerintah berkaitan dengan kepentingan kekuasaan sekaligus usahanya.

Di Indonesia, banyak media terutama televisi - yang secara kepemilikan berada dalam lingkaran politik. Stasiun televisi tersebut menjadi bagian dari strategi media kampanye politik para pemiliknya. Ini tentu sangat bertentangan dengan idealisme media yang seharusnya objektif dan independen. Banyak peneliti menemukan media yang tidak dimiliki oleh politisi, namun dalam pemberitaannya cenderung berpihak pada partai atau calon-calon tertentu. Jika hal ini terus berlangsung, maka realitas kebenaran akan semakin sulit dicari. Realitas politik dan realitas media akan menjadi satu bingkai.

Dalam konteks konglomerasi media yang cenderung mendominasi opini, masyarakat dengan akses media yang tinggi tanpa kecerdasan yang cukup akan cenderung larut dalam arus realitas kebenaran media yang sudah berbalut 
politis. Kebenaran media yang bersifat politis dengan demikian akan mendominasi wacana publik dalam melihat sebuah persoalan.

Dalam konteks media relations, situasi ini semakin mempersulit praktisi hubungan masyarakat dalam menyusun strategi media untuk kepentingan organisasi. Politik sangat sulit dikendalikan dan tidak linier dengan aturan hukum positif, sehingga politisasi kebijakan akan sangat mungkin terjadi. Hal ini akan cenderung menguntungkan pihak-pihak tertentu dan merugikan pihak yang lain.

Tanpa adanya aturan yang memagari, persaingan antarmedia akan menjadi semakin tidak sehat. Politisi yang posisinya kuat akan dengan mudah memengaruhi kebijakan untuk menjatuhkan posisi lawan politik dan sekaligus para pesaing usahanya. Regulasi tentang media dan siaran secara ideal harus diatur sedemikian untuk melindungi kepentingan semua pihak yang terlibat dari eksistensi media di masyarakat.

\section{Penutup}

Media merupakan elemen penting dalam menjembatani kepentingan organisasi dalam menyampaikan informasi guna pembangunan citra korporasi maupun produk pada masyarakat untuk memenuhi kebutuhan informasi. Penyusunan strategi yang tepat berbasis data akurat menjadi kunci keberhasilan kegiatan media relations.

Pemetaan media merupakan langkah yang penting untuk memotret gambaran media yang berpotensi untuk dijadikan partner dalam melakukan publikasi. Pemetaan media dilakukan untuk mengetahui keseuaian media untuk menjangkau publik dan kredibilitas media, terkait objektivitas dan independensinya dalam mengelola redaksinya. Independensi dan objektivitas media merupakan syarat mutlak agar organisasi-organisasi dapat bersaing secara sehat dalam melakukan upaya publikasi melalui media di luar jaringan.

Pewujudan independensi dan objektivitas harus selalu diperjuangkan dan dijaga melalui regulasi, lembaga pengawas, maupun masyarakat luas. Dalam konteks media relations, para praktisi hubungan masyarakat harus selalu mengikuti dan mencermati fenomena kecenderungan kepemilikan media yang dimiliki oleh para pengusaha nonmedia dan pengusaha sekaligus politikus. Pemetaan media yang baik dan dilakukan secara rutin akan memberikan solusi bagi organisasi untuk terhindar dari strategi blunder yang justru akan merugikan. Efek-efek kepemilikan yang menciptakan kolaborasi media, usaha nonmedia, dan politik, atau kaitan-kaitan antara unsur-unsur tersebut, harus diantisipasi sedemikian rupa oleh organisasi untuk menghasilkan keputusan terbaik dalam kegiatan media relations. 
Kesalahan-kesalahan dalam mencermati dan melakukan analisis harus benar-benar diminimalkan agar kedalaman relasi antara variabel bisa lebih detil sehingga rekomendasi yang diberikan juga lebih akurat.

Hubungan media yang kondusif akan terjadi apabila terpenuhi tiga persyaratan: (1) Kepemilikan media tidak satu konglomerasi dengan usaha nonmedia; (2) Media tidak dimiliki oleh kaum politisi; dan (3) Media seimbang dalam orientasi ekonomi dan orientasi informasi masyarakat.

Selain itu, menghadapi fenomena kepemilikan media maka para praktisi hubungan masyarakat seharusnya: (1) Melakukan pemetaan ulang terhadap media secara rutin baik terhadap media lama maupun media baru; (2) Selalu mengkaji perubahan-perubahan kebijakan media baik di manajemen organisasi (faktor organisasional) maupun manajemen redaksi. Sebab, faktor-faktor organisasional memiliki hubungan erat dengan faktor-faktor redaksional termasuk hubungan antara media dengan organisasi eksternal.

Untuk mewujudkan kondisi ideal, organisasi apapun yang membutuhkan kehadiran media sebagai sarana publikasi sudah seharusnya ikut berpartisipasi dalam mendorong perubahan regulasi tentang media dan penyiaran, termasuk pengaturan tentang kepemilikan media. Proses deregulasi tentang kepemilikan media, media (pers), dan penyiaran harus dikawal sedemikian rupa agar tidak hanya menguntungkan kelompok-kelompok tertentu dan cenderung merugikan kelompok lain, terutama masyarakat luas. Bagaimanapun, jika masyarakat sudah tidak memiliki cukup kepercayaan terhadap media, maka praktisi hubungan masyarakat sudah selayaknya untuk mempertimbangkan ulang penggunaan media massa sebagai sarana publikasi dan mulai memilih media alternatif untuk menjangkau publiknya.

\section{Daftar Pustaka}

Bland, Michael, David Wragg, Alison Theaker. 2005. Effective Media Relations: How To Get Results. London: Kogan Page.

Bok, H.S, Kankanhalli, A., et.al. 2012. "Revisiting Media Choice: A Behavioral Decision-Making Perspctive", dalam International Journal of e-Collaboration. Volume 8 Issue 3, July 2012., pp. 19-35.

Cahyadi, Firdaus. 2011. Konglomerasi Media di Era Konvergensi Telematika. www.satudunia.com, diakses 21 Oktober 2012. 
Doyle, Gillian. 2002. Media Ownership: The Economics and Politics of Convergence and Concentration in UK and European Media. London: Sage.

Iriantara, Yosal. 2005. Media Relations: Konsep, Pendekatan, dan Praktik. Bandung: Simbiosa Rekatama Media.
Smith, Craig \& Sarah Crachiolo. 2007. "Media Conglomeration and The News”. Wall Street Journal, edisi 6. 
Jurnal komunikasi, Volume 7, Nomor 1, Oktober 2012 